\title{
Computing with Relevance and Purpose: A Review of Culturally Relevant Education in Computing
}

\author{
Jessica Morales-Chicas \\ Cal State University, Los Angeles \\ U.S.A. \\ Mauricio Castillo \\ Cal State University, Los Angeles \\ U.S.A. \\ Ireri Bernal \\ Cal State University, Los Angeles \\ U.S.A. \\ Paloma Ramos \\ Cal State University, Los Angeles \\ U.S.A. \\ Bianca L. Guzman \\ Cal State University, Los Angeles \\ U.S.A.
}

ABSTRACT: The purpose of the present review was to identify culturally responsive education (CRE) tools and strategies within K-12 computing education. A systematic literature review of studies on CRE across 20 years was conducted. A narrative synthesis was applied to code the final studies into six themes: sociopolitical consciousness raising, heritage culture through artifacts, vernacular culture, lived experiences, community connections, and personalization. These common themes in CRE can help empower and attend to the needs of marginalized students in technology education. Furthermore, the review serves as an important overview for researchers and educators attempting to achieve equity in computing education.

KEYWORDS: ethnocomputing, culturally responsive computing, culturally responsive teaching, technology, equity

Inequities in Technology and Computer Programming Method

Results and Discussion

Limitations and Future Directions

Conclusion

References

Appendix A

Appendix B

Author Contact 
Computer programming, also known as computing (i.e., the teaching of computing languages like Java, $\mathrm{C++}$, and $\mathrm{HTML}$ ), became popularized in $\mathrm{K}-12$ education in the 1980 s but has now re-emerged as a way to equip youth with technological skills to transform the world (Lee et al., 2011; Papert, 1980). Despite the rise in attention to computing in schools, barriers persist in the access, relevance, and participation in computing for underrepresented populations (Margolis, Goode, \& Bernier, 2011; Margolis, 2010). Thus, various scholars and educators have discussed the importance of using culturally relevant practices in computing education to diversify the field of computer science (Charleston, Charleston, \& Jackson, 2014; Scott, Aist, \& Hood, 2009). To better understand the composition, strengths, and challenges of culturally relevant computing approaches in K-12 education, a review of empirical articles on this topic is needed. We address this gap in the literature by taking several steps to accumulate and analyze articles on this topic. We first conducted a narrative review to identify the main culturally relevant education theories and tools used in computer programming education. These theories and tools were then used as key terms that guided our systematic review of culturally relevant computing education articles from the past 20 years. The resulting articles were analyzed using a narrative synthesis approach that identified six common themes, introduced later in this paper. While research on this topic is still emerging, this review offers researchers, educators, and computer programmers recommendations that can potentially help increase the accessibility and relevance of computing education for underrepresented students.

\section{Inequities in Technology and Computer Programming}

With the rise of a modern technological world, increasing access to technology has been at the forefront of many conversations in research, policy, and practice. For years, efforts to close the digital divide focused on providing more physical proximity to technology across racial and socioeconomic status groups (Prensky, 2001). However, for digital natives who were born into a world where technology is commonplace (Prensky, 2001), everyday use of pocket-sized smartphones and media devices has masked the reality that social, cultural, and political gaps in technology continue to exist. Ignoring these gaps can increase inequities in technology that will disproportionately impact lower income communities of color (Gorski, 2009).

One step toward decreasing inequities in technology is to focus on allowing students to advance their computing fluency so they can become leaders in the technology workforce. Currently, careers involving computing (e.g., being a software application developer) are expected to grow rapidly and pay higher wages than any other Science, Technology, Engineering, and Math (STEM) field (Fayer, Lacey, \& Watson, 2017). Despite this projected growth, people of color remain underrepresented in computer science professions (Scott, Martin, McAlear, \& Madkins, 2016). Barriers in the computer science pipeline are often perpetuated by the lack of access or relevance to computer programming courses, especially in under-resourced schools (Araque et al., 2013; Margolis, 2010; Wang, Hong, Ravitz, \& Hejazi Moghadam, 2016). Over time, existing barriers further disenfranchise lower-income communities of color from potential 
careers in computing (Goode, 2008; Margolis et al., 2011; Scott, Aist, \& Hood, 2009). To tackle this social equity concern, efforts to increase computer science opportunities should include ways to effectively reach and teach computational skills to underserved populations in order to strengthen the pipeline to the technology industry.

\section{The Present Review}

One strategy for effectively reaching traditionally marginalized populations in computing is to integrate students' identities (e.g., culture or gender) into the practice of teaching computing education (Grover \& Pea, 2013). Prior research suggests that increasing the relevance of students' background in computing allows for better student learning outcomes, advances thinking, and empowers students with more positive reflections of the self (Ashcraft, Eger, \& Scott, 2017; Eglash, Gilbert, \& Foster, 2013; Frederick, 2007; Lee et al., 2011). Unfortunately, most computing experts tend to lack experience working with children or have limited knowledge of applying educational theory into the classroom (Ben-Ari, 2004). Thus, it is important to equip the computing education field with tools for implementing developmentally appropriate practices and culturally sensitive teaching methods. However, there has yet to be a review that examines what these practices look like, how they compare to each other, and what challenges are associated with implementing these computing approaches within K-12 education. Therefore, the present review helps accumulate and analyze related literature that uses culturally relevant teaching methods in computing in order to inform educators and researchers of effective practices.

\section{Guiding Framework: Culturally Relevant Education}

To help guide the present review, it is important first to introduce the definitions, purposes, and benefits of applying a culturally relevant education. For many educators, multicultural education serves as a classic approach for promoting cultural diversity (Banks, 2013). However, traditional uses of multicultural education are often criticized for the over-reliance on cultural symbols (e.g., food and holidays) that prescribe a stereotypical perspective on the meaning of culture. As an example, teachers applying multicultural education may base their curriculum on pre-determined and unilateral concepts of culture that can produce adverse stereotypes (Kim \& Slapac, 2015). These issues with multicultural education have resulted in preference toward other theories promoting cultural relevance.

Across the education literature, two prominent frameworks have set the tone for incorporating cultural relevance into education through a social justice lens. Foremost, culturally responsive teaching aims to empower students by acknowledging their lived experiences, considering frames of reference, and setting high standards for students of diverse cultural backgrounds (Gay, 2002, 2013). Gay (2010) posits that, within culturally 
responsive teaching, students' strengths serve as an anchor in the process of transforming traditional teaching practices that have oppressive histories. Therefore, the learning process is student-centered and based on the needs of the students (Gay, 2013). The second seminal work on this topic comes from Ladson-Billings $(1994,2014)$ who coined the term culturally relevant pedagogy. Unlike culturally responsive teaching, which focuses on the methods of teaching, culturally relevant pedagogy relies more on describing the approaches and attitudes that help guide the curriculum (Aronson \& Laughter, 2016). Furthermore, culturally relevant pedagogy leverages students' cultural referents in the curricular planning process and challenges social inequities to transform the learning context (Ladson-Billings, 1995a, 1995b). Despite differences, it is clear that both frameworks use a social justice lens that empowers students by seeing their identities as an asset. Together, these participatory approaches have the potential to impact both students and teachers while promoting academic achievement (Brown-Jeffy \& Cooper, 2011; Howard \& Clarence, 2011).

One of the issues in constructing a review with these frameworks is that culturally responsive teaching and culturally relevant pedagogy are often used interchangeably in the literature. Aronson and Laughter (2016) recognized the interchangeable use of these terms when generating their own systematic review of culturally responsive and relevant approaches in education. In response, these researchers combined the two frameworks within their review search and referred to them as culturally relevant education. For simplicity, the present study will emulate this approach and refer to Gay's (2013) and Ladson-Billings' (2014) work as culturally relevant education (CRE).

Given persistent disparities in the computing industry, infusing CRE in computing may broaden participation from people traditionally marginalized in this space. While researchers are making great strides in CRE computing practices, no articles to our knowledge have systematically reviewed and organized the literature into identifiable themes that inform best practices. Therefore, the present research investigates three research questions, each of which requires distinct methodological steps to help identify, compile, and analyze published articles featuring CRE in computing education. The three research questions are as follows:

1. What are the main culturally relevant education (CRE) theories and tools of praxis used within K-12 computer programming? To address this question, a narrative review of published research was first conducted to locate the main CRE theories and tools used in computing education.

2. Of the common theories and tools of praxis in CRE, what strategies are applied to empower or integrate students' background or culture within computer programming K-12 education? To address this research question, the main theories and tools of praxis that resulted from our narrative review served as key terms in our systematic literature review of articles on CRE in computing education. These articles were then coded to delineate the main strategies applied in CRE computing education.

3. What are the challenges and strengths in CRE approaches and how can educators and researchers leverage these tools to help close the digital divide? 
To answer the final research question, each article from the systematic review was coded and analyzed in order to identify the strengths, limitations, and future directions of each CRE approach.

\section{Method}

\section{Initial Search Strategy}

To address the first research question, a narrative search (Green, Johnson, \& Adams, 2006) was conducted to allow for the identification of the prominent CRE theories and frameworks in computing education. Due to the junction of two distinct disciplines (i.e., education and computing), Google Scholar was used first to assess the breadth of relevant studies on this topic. Initial search terms included computer programming and education, culturally relevant teaching in computing, and culturally relevant teaching and technology. This initial search resulted in thousands of articles that picked up on the singular reference of each word (e.g., education); as a result, we became further convinced of the need for a more systematic review process. Nonetheless, our interdisciplinary team of researchers in the fields of education, human development, technology, and psychology read through multiple abstracts from this search and met several times to discuss and converge the findings. This initial search assisted the team with determining and confirming existing CRE theories and concepts in computing education. Moreover, this informal search provided a direction for the selection of key words that would guide the systematic review in this paper.

\section{Inclusion Criteria for the Systematic Review}

Based on a preliminary review of the literature, three theories and/or concepts emerged regarding CRE in computing. These topics were used as key terms in the systematic review; they included ethnocomputing, culturally responsive computing, and Culturally Situated Design Tools. The term e-textiles was also added as a key term because it is an innovative tool that can incorporate CRE approaches in computing. Etextiles are textile garments in the form of thread, yarn, or other fabrics that are infused with light emitting diode (LED) wire to create wearable pieces that light up (Peppler, 2013). In addition to this list of key terms, identifier terms were used to refine this search (i.e., culture, race, minorities). Appendix A provides a complete list of key word combinations for this search.

The next phase of our research was a systematic review consisting of a more detailed, intentional, and rigorous search process (Petticrew \& Roberts, 2006). Three databases that typically cover topics in culture, computing, technology, and education were selected: JSTOR Arts and Sciences, Web of Science, and ERIC. Only published 
English language peer-reviewed journal articles were considered. Furthermore, with technology being a rapidly changing industry, only research from the last 20 years (i.e., 1998 to 2018) was considered to capture contemporary applications of computer programming in $\mathrm{K}-12$ education. Using these search criterions yielded a total of 52 articles that were carefully examined to confirm the inclusion of CRE within $\mathrm{K}-12$ computing education. In total, 22 of the 52 articles involved this topic. Our final review included 5 of the 13 articles from JSTOR, 6 of the 22 articles from ERIC, and 11 of the 17 articles from Web of Science. Any article that appeared in more than one database was counted only once.

\section{Narrative Synthesis Procedure}

To analyze the results of our systematic search and to address our second and third research questions, we applied a modified approach to Popay and colleagues' (2006) general framework for conducting a narrative synthesis. The first step of this framework was the preliminary synthesis involving a coding process of the 22 final studies. The following data were carefully examined and coded for each study: author and year, purpose, participant description, methodological approach, and summary major findings. Moreover, inductive and open coding techniques were applied to identify the multiple themes in each study. In alignment with Popay and colleagues' (2006) recommendations, we also explored the relationships and differences between each article. A second researcher reviewed each study to cross-validate the findings. Lastly, to expand the robustness of the synthesis, the challenges and strengths in the CRE approaches were identified. Using this knowledge, we devised a set of recommendations and cautions that should be considered when implementing CRE in computing education.

\section{Results and Discussion}

\section{Preliminary Narrative Review Findings}

In answering our first research question, the initial narrative review of the literature resulted in three prominent CRE theories or tools used within K-12 computer programming: ethnocomputing, Culturally Situated Design Tools, and culturally responsive computing. The first section of the results will provide an overview of these topics.

Ethnocomputing. One of the main approaches to CRE in computing is called ethnocomputing (Tedre, Sutinen, Kähkönen, \& Kommers, 2006). Ethnocomputing was inspired by the seminal work of D'Ambrosio (1985) on ethnomathematics, which bridged the relationship between culture and math. Similar to the study of ethnomathematics, Tedre and associates (2006) proposed that analogous to math, computing is not culturally neutral; that is, computing principles are actually shaped from culturally informed logic 
stemming from Western ideals, customs, and beliefs (Tedre et al., 2006). As a result, researchers contend that computing should instead be taught using techniques that consider the cultural context of the user. Ethnocomputing was born from this premise and suggests that computing principles should relate to the learners' cultural framework (Babbitt, 2014; Tedre et al., 2006). As an example, Tedre et al., (2006) argue that something as simple as a mailbox or folder icon in an email interface is symbolic of items used in the Western world and such items are not universal symbols. However, when applying ethnocomputing, relevant cultural artifacts and referents of the local user are considered in contemporary computing simulation, allowing for the practice of multiculturalism in computer science education (Babbit, Lyles, \& Eglash, 2012; Tedre, 2002).

Culturally Situated Design Tools. Users of ethnocomputing rely on Culturally Situated Design Tools (CSDT) as a medium to create visual programming techniques (Babbitt, Lyles, \& Eglash, 2012). As such, CSDTs can include Java and flash applications that focus on a particular cultural practice or artifact (Babbitt et al., 2012). Moreover, the creation of CSDTs requires a collaborative approach with community members in order to identify assets from communities that are not typically considered in computing (Eglash, Bennett, O'Donnell, Jennings, \& Cintorino, 2006). As an example, Lachney's (2017) Cornrow Curves project leveraged techniques used in cornrow hair braiding to create a CSDT application with collaboration between researchers, hair braiders, software developers, students, and teachers. Through this process, the CSDT technique moves away from relying on traditional programming platforms for youth that are often based on commercial mainstream topics (e.g., Barbie and Power Rangers), instead using tools that empower students by leveraging assets in their communities (Lachney, 2017; Lachney, Babbitt, \& Eglash, 2016).

Culturally responsive computing. Another culturally responsive framework within the computing education practice is called culturally responsive computing (CRC). CRC was inspired by the principles of culturally relevant education theories, which motivate students to reflect and take an asset-based lens to computer programming (Eglash, Gilbert, \& Foster, 2013). In comparison to ethnocomputing, CRC encourages participants to collectively engage, reflect, and build while challenging the status quo in computing (Scott, Aist, \& Zhang, 2014). Scott, Aist, and Zhang (2014) also state that "CRC encourages teachers to reflect on their participation in (de)constructing the digital knowledge economy" (p. 267). Scott et al. (2015) further propose that CRC encourages a movement toward equity in STEM by framing curriculum through a social critique lens. In one application of CRC, Scott et al. (2014) created a program called COMPUGIRLS that taught computational skills using culturally relevant practice. The COMPUGIRLS curriculum discussed and practiced computing while considering culture, language, gender, race, and other social identities. The ultimate goal of a CRC project like COMPUGIRLS is to provide a deeper understanding and appreciation of one's identities, background, or culture through computing experiences (Scott et al., 2015).

Together, ethnocomputing, CSDTs, and culturally responsive computing help move the needle toward equity in computing by considering the many forms of cultural wealth that underrepresented populations bring to the computing process. These theories 
and tools, therefore, guided our systematic investigation and helped us outline the novel ways educators and computer scientists help address the digital divide.

\section{Narrative Synthesis of the Systematic Review}

The next set of results presents themes from the narrative synthesis of articles from the systematic review. A total of six themes or strategies that are commonly implemented in K-12 CRE computing were found. In no particular order of importance, the themes were as follows: (a) sociopolitical consciousness raising; (b) heritage culture through artifacts; (c) vernacular culture; (d) lived experiences; (e) community connections; and $(\mathrm{f})$ personalization. Categorization of studies into these themes was not mutually exclusive, with some articles fitting across multiple themes. Tables 1 through 4 (Appendix B) delineate which themes were identified for each article, along with an overview of each study.

Theme 1: Sociopolitical consciousness raising. The first theme involving the practice of CRE in computing is the topic of sociopolitical consciousness raising. This theme is defined as a practice in computing that allows students to reflect and build awareness of current social-political issues in the world, thereby inspiring activism. This theme aligns well with the central tenet of culturally responsive computing (CRC), which aims to address social justice issues in participants' communities (Scott, Sheridan, \& Clark, 2015). Social justice refers to the "fair and equitable allocation of bargaining powers, resources, and obligations in society in consideration of people's differential power, needs and abilities" (Prilleltensky, 2001, p. 754).

Many of the studies in this theme (e.g., Scott, Aist, \& Hood, 2009) involved CRC approaches pertaining to a project called COMPUGIRLS. As can be seen in Table 1 (see Appendix B), Scott et al. (2009) described the planning and implementation phases of five CRC pilot studies. Each pilot study was related to a social justice cause, such as the use of geographic information systems (GIS) to capture neighborhood food availability. Other software applications covered topics from violence, diversity in voting patterns, public transportation, and diversity in game avatars. This article suggested that CRC is effective when lessons are student-centered, customizable, and related to real world social justice concerns. Scott and Garcia's (2016) article also described the COMPUGIRLS program as fostering activism in girls of color by using a critical lens to identify and address social injustices as technologists (see Table 1). In their essay they critiqued neoliberal educational approaches in technology and encouraged users to take an anti-deficit lens of identity portrayal in computing. The paper ended by showcasing a lesson examining the values embedded in the avatar design process. In a separate article, Scott et al. (2015) provided another overview of their current applications of CRC within COMPUGIRLS. Through this theoretical article, the authors reconceptualized the CRC framework by devising five tenets. Together, the tenets proposed that CRC is a transformative tool for anyone to engage in technology while encouraging self-reflection and identity development. Overall, CRC approaches within COMPUGIRLS all considered the concept of identity formation through an intersectionality (Crenshaw, 1991) 
framework, which considers the ways various systems of oppression converge when social identities overlap.

Although studies in this theme tended to focus on similar projects related to COMPUGIRLS, only a few incorporated an evaluation strategy. Foremost, Ashcraft, Eger, and Scott (2017) used ethnographic research involving $8^{\text {th }}$ and $9^{\text {th }}$ graders to evaluate a COMPUGIRLS program. The results showed increases in critical awareness regarding the ways technology platforms perpetuate privilege and inequality. Contrasting perspectives among two participating cohorts showed that some students experienced difficulty in discussing topics of inequality while others evolved into techno-social change agents (i.e., resisters of dominant frameworks that assert privilege) (Ashcraft et al., 2017). Similarly, Scott and White's (2013) qualitative evaluation efforts (e.g., observations) of another COMPUGIRLS case study investigated the effectiveness of their CRC methods. They found that adolescent girls not only felt empowered and committed to the program but also developed an identification of themselves as technology innovators. In sum, these studies demonstrate the positive impact of promoting sociopolitical consciousness raising in computing innovations.

The theme of sociopolitical consciousness raising was also introduced in Eglash, Bennett, Drazan, Lachney, and Babbitt's (2017) review of ethnosciences (see Table 4 in Appendix B). In this study, Eglash and associates (2017) encouraged a generative justice approach to technology, which involves computing that promotes learning, the common good, and sustainability. By considering the social implications of ethnocomputing, these scholars urged researchers to become active social theorists. Moreover, the researchers posited that using a social justice lens and a participatory process can help increase computing and math skills for participants (Eglash et al., 2017).

Despite the benefits of this approach, promoting consciousness about social or political issues in computing opposes dominant ideologies, which can provoke controversy. With this in mind, educators are encouraged to take into account their own positions of power and biases when raising sociopolitical consciousness in computing. For example, group dialogue aimed to inspire such projects must consider the polarizing dynamics that can emerge in a discussion of social justice issues, especially when the teacher does not reflect the students' background (Ashcraft et al., 2017). Additionally, when applying a CRC curriculum, Scott et al. (2009) recommend establishing and maintaining healthy group dynamics between youth to ensure comfort. Considering these multiple recommendations can help educators and software developers foresee complications related to this approach.

Theme 2: Heritage culture through artifacts. Table 2 (see Appendix B) provides a summary of the studies representing applications of CRE in computing, while considering heritage culture through artifacts. Cultural heritage is described as culture that is transferred through ancestral roots (Eglash, Gilbert, Taylor, \& Geier, 2013). Most studies considering heritage culture through artifacts used ethnocomputing as pedagogical practice. In accordance, a review by Anohah and Suhonen (2016) analyzed studies on constructivist perspectives focusing on cultural heritage; the findings from their review showed that articles on ethnocomputing tended to focus on incorporating indigenous cultural perspectives in computing. The authors explained that including 
heritage culture in computing should consider cultural awareness and cultural adaptability (i.e., the ability to transfer technology applications in the proximal culture). More importantly, Anohah and Suhonen's (2016) review helped in devising a framework for applying ethnocomputing to non-Western contexts.

Overall, studies using heritage culture through artifacts showed positive outcomes. For instance, Eglash, Krishnamoorthy, Sanchez, and Woodbridge (2011) used a quasiexperiment with predominately African American high school students to assess the effectiveness of African architectural design principles in computing. Students who received the heritage-based design showed an enhanced understanding of recursion (i.e., one of the basics of fractal geometry), greater accuracy in computing, and an increase in learning about computing and culture. Another approach to this work by Babbitt, Lachney, Bulley, and Eglash (2015) used mathematical principles taken from Ghanaian Adrinkra symbols to design a CSDT computing software within ethnocomputing. Table 2 displays that the participating middle school students in Ghana showed increases in mathematical performance. Additionally, Eglash and colleagues (2013) compared two pilot evaluations of CRC: one using vernacular culture and the other using heritage culture. Their quasi-experiment concluded that students showed improvement in interest and attitudes when applying CSDT tools. Together, these studies document the positive implications of applying this theme in computing.

Although there is great value in the involvement of heritage culture in programming, it is important to illuminate the issues that can arise in CSDT applications. Foremost, Eglash et al. (2013) found that when given a choice, students showed preference for other approaches over heritage-related projects; however, students' excitement increased after receiving training on the project. Thus, heritage culture artifacts must be properly introduced and should consider participants' understanding of their ethnicity. Eglash, Bennett, O'Donnell, Jennings, and Cintorino (2006) also encouraged negotiation of cultural artifacts with the students and community members in order to prevent cultural appropriation (i.e., taking cultural artifacts without permission outside the original context). More interestingly, they alert readers of the intricacies of considering cultural heritage, especially for White participants who reflect the dominant American culture. With consideration of these cautions, interventions like this have the potential to increase math achievement and challenge deficit perspectives about underrepresented students in computer science (Eglash et al., 2006).

Theme 3: Vernacular culture. Contrary to a focus on cultural heritage, vernacular culture encompasses the local social environment of participants (Eglash et al., 2013b; Eglash, Bennett, Drazan, Lachney, \& Babbitt, 2017). In this theme, two studies previously discussed in Theme 1 are also featured. The first study by Eglash et al. (2013b) described examples of prior projects using vernacular culture involving topics like street art and breakdancing. They also specifically discussed a programming tool called "African American Distributed Multiple Learning Styles Systems" (AADMLSS) (p. 636) that the authors created with the intent to embed CRE tenets to reach urban African American youth. In this intervention, a virtual math game allowed participants to manipulate the characters to reflect their vernacular culture. The results showed higher youth engagement to this task because of the increased cultural alignment (see Table 2). When 
compared to heritage cultural artifact applications, vernacular culture (e.g., Latino students using the Graffiti Grapher) also showed more positive increases in math achievement (Eglash et al., 2006). Together, these studies draw on elements of CRE and highlight the importance of considering students' proximal milieu.

A distinct study by Eglash and Bennett (2009) also used vernacular culture via a CSDT software called Cornrow Curves. This project taught math algorithms in computing by applying patterns from the cultural practice of hair braiding with African American girls (See Table 2). Eglash and Bennet (2009) built this tool because they believed that "cornrows have a remarkable repertoire of nonlinear patterns, often resulting in a complex array of logarithmic curves and other 'scaling' (i.e., fractal) geometries" (p. 60). Results from this CSDT intervention, used with $8^{\text {th }}$ to $12^{\text {th }}$ graders in New York, showed increases in computer use, math performance, attitudes, and ideas about future careers for participants. Using the Cornrow Curves project as reference, Eglash, Bennett, Drazan, Lachney, and Babbitt (2017) also described this programming interface when reviewing topics in ethnocomputing (featured in Table 4). Pre to post results of students in the CSDT class showed greater increases in math and computing skills when compared to students not taking this intervention. Vernacular approaches in CRE incorporate contemporary cultural practices relevant to the participants, which helps engage students in the process.

While vernacular culture can increase relevance of computing for participants, this approach also opens a new set of challenges educators must consider. As an example, studies collected in this section draw attention to the dangers of perpetuating negative stereotypes when integrating cultural scripts in the curriculum. In response, educators are encouraged to consider incorporating vernacular culture that goes beyond what is in front of youth to ideas that can motivate social change (Eglash et al., 2013b; Eglash et al., 2017). Eglash and Bennett (2009) also note that CSDT tools related to vernacular culture tend to focus more on entering values for algorithms rather than having students create their own algorithms. Despite these limitations, using vernacular culture in computing curriculum increases relevance for youth and opens the potential for learning benefits.

Theme 4: Lived experiences. The next theme that directly connected to one of the goals of CRE involved the recognition of students' lived experiences (Ladson-Billings, 1995b). In accordance, Tedre and colleagues' (2006) theoretical discussion of information and communication technologies emphasized the experience of lived experiences when introducing ethnocomputing. Specifically, they stressed how incorporating participants' experiences in the computing curriculum can increase the cultural relevance for the user. To further dissect the studies in this theme, the section on lived experiences is categorized into two parts: connection to the participants' real world context and connection to participants' self-identity.

Connection to the participants' real world context. One of the ways participants' lived experiences were acknowledged in the computing literature was by connecting the curriculum to the real world context. To illustrate, Scott et al. (2009) discussed a lesson from the COMPUGIRLS project, previously mentioned in Theme 1, in which students referenced real world issues from their community contexts (see Table 1). Additionally, Table 4 features Xie and Reider's (2014) study that incorporated geographic information system (GIS) and information assurance (IA) software with real life scenarios. 
Program participants used their own urban community locations to code a GIS map. The direct relevance to the students' real-world environment allowed for increases in STEM learning and interest in STEM careers (Xie \& Reider, 2014). Similarly, DiSalvo, Guzdial, Bruckman, and McKlin's (2014) study showed the advantage of using a real life reference in computing. In this study, the authors examined how high school African American and Latino males negotiated between conflicting identities of being "cool" and "geeking" out as computer science game testers (p. 274). The results of this study showed that by presenting game testing as a real world job that could impact real world products, participants were able to better apply face-saving tactics to maintain their identities, interest, and confidence in computer science. Together, these studies highlight why making computing related to students' real world environments is important.

Connection to the participants' self-identity. Another sub-theme that involved a less tangible aspect of students' lived experience is the incorporation of self-identity into computing education. To demonstrate how self-identity development was approached across technology education, Frederick, Donnor, and Hatley (2009) conducted a literature review of culturally relevant applications in technology education programs (featured in Table 1). They concluded that technology education programs that attempt cultural relevance in their curriculum should consider students' lived experiences and an acknowledgement of self-representations. Furthermore, these authors contend that regardless of how students' lived experiences are approached, it is important to provide tools that can counter and critique deficit narratives (Frederick et al., 2009).

Several studies also discussed the importance of taking an intersectional approach (Crenshaw, 1991) to identity development in CRE. In the theoretical article by Scott et al. (2015) (previously described in Theme 1), the new tenets they proposed for CRC considered the intersecting identities that extend beyond just race or social class, in order to encourage innovation through the perspective of the self and community. In addition, Scott and Garcia (2016) brought attention to intersecting identities when describing their lesson on avatar creation for COMPUGIRLS. By examining the values and characteristics typically placed on avatars, youth were able to reflect on the limitations of these representations and how they reinforced societal norms (featured in Table 1). Ashcraft and associates' (2017) study, previously introduced in Theme 1, also highlighted the importance of youth identity development in technology education. This article specifically discussed the challenges and benefits of facilitating a discussion on intersecting selfidentities (e.g., race or class) as part of the computing curriculum. Through effective dialogue, participants developed a deeper awareness of their identity and its representation in technology (Ashcraft et al., 2017). Thus, attention to intersectional identities is a critical component of CRE that can contribute to identity formation.

Theme 5: Community connections. Another theme that surfaced was the strategy of building community connections involving community members, students, and teachers as brokers of cultural knowledge in computer programming. Lachney (2017) for example (see Table 1), fostered connections between software developers, schools, and students when developing two different software approaches (i.e., Cornrow Curves and Adinkra Computing). In the case of the Cornrow Curves project, community hair braiders provided knowledge of cornrow hair braiding patterns to inform the construction of 
computational patterns in the software algorithms. In addition to vocation experts, youth can also serve as brokers of community cultural knowledge. For example, in a different study, 10 Native American youth helped inform and develop a local museum's web features (see Table 4) (Pohawpatchoko, Colwell, Powell, \& Lassos, 2017). Pohawpatchoko et al. (2017) later found that students who attended workshops on applying aspects of ethnocomputing showed stronger connections to the museum and increased web skills. The strength of building connections also extends to pre-service teachers learning how to administer CRE in technology education. For instance, Chuang's (2016) study (see Table 1) demonstrated how connections among teachers, via cloud computing, increased confidence in administering a CRE curriculum. In total, these studies document the dynamic roles that community connections play when applying CRE to computing.

In attempting to form community connections when developing CRE programming, researchers and practitioners should consider the role and benefits of community advocates. Lachney (2017) made apparent that not all relationships with community members will be mutually beneficial. For example, in the case of Adinkra computing software, the local cultural experts who served as brokers of cultural knowledge for the computing project did not actually benefit from their investment on the project. Cases like this remind us that educators should attempt to develop explicit mutually beneficial partnerships in CRE computing.

Theme 6: Personalization. The last theme found in this review involved the concept of personalization, mostly around the creation of e-textiles. For example, Kafai, Lee, Searle, Fields, Kaplan, and Lui (2014) taught programming and debugging to youth who customized and designed their own e-textiles. When analyzing the 15 high school students' portfolios and interviews about this computing project, researchers found an increase in computing relevance attributed to the personalization of features (see Table 3 in Appendix A). Mirroring this work, Kafai, Fields, and Searle (2014) examined the experiences of students personalizing their e-textiles within workshops (also featured in Table 3). The findings from field notes and interview data showed that students who engaged in e-textiles developed a deeper understanding of the inner workings of programming circuits (e.g., how things come apart, the function of each piece, and how each piece is put back together). Moreover, allowing for personalization showcased students' artistic design while drawing attention to aesthetics in diverse approaches to computing. Also, as featured in the e-textile Table 3, Tofel-Grehl et al. (2017) compared an e-textiles learning approach to a more traditional circuitry project with $1558^{\text {th }}$ graders. Results from the quasi-experiment showed that participants were excited to showcase their personalized work, and in turn, positive attitudes toward science were found. These studies suggest that computing projects involving e-textiles have the ability to promote personalization in projects that are student-centered and serve to foster positive STEM outcomes.

Despite the benefits of customization, there are various challenges that can arise when implementing personalization in projects, especially with e-textiles. Kafai, Fields, and Searle (2014) caution educators attempting to use e-textiles in school to consider the limited time presented in the classrooms, due to the competing demands of standard 
curriculums. Also, when focusing on aesthetics and art in personalization, it is important not to reinforce gendered stereotypes around practices with crafts (Kafai et al., 2014). Nevertheless, in addressing these barriers, e-textiles provide a powerful tool for youth to have fun while learning with CRC.

\section{Limitations and Future Directions}

Altogether, the studies in this review provided comprehensive examples of frameworks, programs, and lessons that can be applied when using CRE in computing education. However, most of the studies found in this review represented a collection of works by the same prominent scholars in each computing niche. Moreover, only a few students were typically being served or evaluated in each study, as Tables 1 through 4 display. As a result, conclusions drawn from these studies and generalizability of findings should be cautioned. To improve future studies of CRE in computing education, researchers should consider including larger and more diverse samples. In practice, multidisciplinary teams that traverse myriad forms of expertise could also help expand future work (Lachney, 2017).

Many of the articles applying CRE in computing exhibited limitations concerning methodology and evaluation strategies. Like other research in education settings, most studies used quasi-experimental designs involving pre and post-tests to evaluate learning outcomes. However, studies often lacked a comparison group that could strengthen causal inference. Future research in this area could benefit from an intervention study in which some students are randomly assigned to a treatment group that teaches CRE in computing education and others to a control group (e.g., a computing class not applying a CRE curriculum). Waitlist control groups could also be used with one group receiving the intervention after the active treatment group. For a review on ways to improve quasiexperiments to maximize external and internal validity see Handly, Lyels, McCulloch, and Cattamanchi (2018). Finally, longitudinal studies are recommended to better assess the potential long-term benefits of CRE in computing education.

With the field of computing only recently reemerging in education, studies on ways to embed culturally relevant education practices in computing are still budding. Thus, the relatively limited number of articles found may have resulted from only allowing published journal articles in this review. In other words, rich applications of CRE in computing education could have been excluded if they were featured in conference papers, dissertations, theses, and books, places in which novel ideas often form. Additionally, although three databases were carefully selected for this review, this certainly does not represent an exhaustive representation of possible databases. Regardless, the small number of studies mirrors other reviews on technology education such as Lye and Koh's (2014) inclusion of only 27 studies. Collectively, these limitations suggest that the field of CRE in computing and also technology education is still nascent. Nonetheless, these fields are burgeoning as the pressure to close technology gaps remains pressing. 


\section{Conclusion}

This literature review provided an overarching summary and discussion of the various strengths and challenges of implementing CRE in computing education in K-12. The results from our search demonstrated a total of six common themes that encompassed how CRE is applied in computing education: sociopolitical consciousness raising, heritage culture through artifacts, vernacular culture, lived experiences, community connections, and personalization. While studies have previously reviewed work involving CRE in technology education, this is the first systematic review of its kind that considers multiple theoretical approaches (e.g., ethnocomputing and CRC) of CRE in computing education. The resulting themes have direct implications for informing best practices for educators, researchers, students, programmers and those who are advocates of closing the digital divide. However, we caution readers to use this review only as a guide and to refer to the studies themselves to learn how to implement each approach. We also encourage programmers to provide open access and circulation of code to communities in order to build sustainable and replicable projects (Eglash et al., 2017). By allowing traditionally marginalized students in computing to innovate with topics directly related to them, we assist in the restructuring of the current landscape of computer science (Eglash et al., 2013a; Scott et al., 2015). In sum, CRE is a promising framework that can be applied to computing by allowing programmers to feel empowered, be critical change agents, and be self-reflective of their self-identities.

\section{References}

Anohah, E., \& Suhonen, J. (2016). Constructivist research framework for integrating indigenous knowledge into computing education. International Journal of Learning Technology, 11(4), 323-339. doi:10.1504/ijlt.2016.08171

Araque, J. C., Maiden, R. P., Bravo, N., Estrada, I. Evans, R., Hubchik, K., ...Reddy, M. (2013). Computer usage and access in low-income urban communities. Computers in Human Behavior, 29(4), 1393-1401. doi:10.1016/ j.chb.2013.01.032

Aronson, B., \& Laughter, J. (2016). The theory and practice of culturally relevant education: A synthesis of research across content areas. Review of Educational Research, 86(1), 163-206. doi: 10.3102/0034654315582066

Ashcraft, C. Eger, E. K., \& Scott, K. A. (2017). Becoming technosocial change agents: Intersectionality and culturally responsive pedagogies as vital resources for increasing girls' participation in computing. Anthropology \& Education Quarterly, 48(3), 233-251. doi:10.1111/aeq.12197

Babbitt, W. E. (2014). Ethnocomputing: The design and assessment of culture-based learning software for math and computing education (Doctoral dissertation, 
Rensselaer Polytechnic Institute). Retrieved from https://search-proquestcom.mimas.calstatela.edu/docview/1658783334?pq-origsite=gscholar

Babbitt, W., Lachney, M., Bulley, E., \& Eglash, R. (2015). Adinkra mathematics: A study of ethnocomputing in Ghana. REMIE Multidisciplinary Journal of Educational Research, 5(2), 110-135. doi:10.17583/remie.2015.1399

Babbitt, B., Lyles, D., \& Eglash, R. (2012). From ethnomathematics to ethnocomputing. In Swapna Mukhopadhyay \& Wolff-Michael Roth (Eds.). Alternative forms of knowing mathematics (pp. 205-219). doi: 10.1007/978-94-6091-921-3_10

Banks, J. A. (2013). The construction and historical development of multicultural education, 1962-2012. Theory into Practice, 52(sup1), 73-82. doi: 10.1080/00405841.2013.795444

Ben-Ari, M. (2004). Situated learning in computer science education. Computer Science Education, 14(2), 85-100. doi: 10.1080/08993400412331363823

Brown-Jeffy, S., \& Cooper, J. E. (2011). Toward a conceptual framework of culturally relevant pedagogy: An overview of the conceptual and theoretical literature. Teacher Education Quarterly, 38(1), 65-84.

Charleston, L. J., Charleston, S. A., \& Jackson, J. F. (2014). Using culturally responsive practices to broaden participation in the educational pipeline: Addressing the unfinished business of Brown in the field of computing sciences. The Journal of Negro Education, 83(3), 400-419.

Chuang, H. (2016). Leveraging CRT awareness in creating web-based projects through use of online collaborative learning for pre-service teachers. Educational Technology Research and Development, 64(4), 857-876. doi: 10.1007/s11423016-9438-5

Crenshaw, K. (1991). Mapping the margins: Intersectionality, identity politics, and violence against women of color. Stanford Law Review, 43(6), 1241-1299. doi:10.2307/1229039

D'Ambrosio, U. (1985). Ethnomathematics and its place in the history and pedagogy of mathematics. For the Learning of Mathematics, 5, 44-48.

DiSalvo, B., Guzdial, M., Bruckman, A., \& McKlin, T. (2014). Saving face while geeking out: Video game testing as a justification for learning computer science. Journal of the Learning Sciences, 23(3), 272-315.

Eglash, R., \& Bennett, A. (2009). Teaching with hidden capital: Agency in children's computational explorations of cornrow hairstyles. Children, Youth and Environments, 19(1), 58-73.

Eglash, R., Bennett, A., Drazan, J., Lachney, M., \& Babbitt, W. (2017). A mathematical tool kit for generative justice. ETD-Educação Temática Digital, 19(3), 761-785. doi:10.20396/etd.v19i3.8648374 
Eglash, R., Bennett, A., O'Donnell, C., Jennings, S., \& Cintorino, M.(2006). Culturally situated design tools: Ethnocomputing from field site to classroom. American Anthropologist, 108(2), 347-362. doi:10.1525/aa.2006.108.2.347aa

Eglash, R., Gilbert, J. E., \& Foster, E. (2013). Toward culturally responsive computing education. Communications of the ACM, 56 (7), 33-36. doi:10.1145/2483852.2483864

Eglash, R., Gilbert, E. J., Taylor, V., Geier, S. R. (2013) Culturally responsive computing in urban, after-school contexts: Two approaches. Urban Education, 48(5), 629656. doi:10.1177/0042085913499211

Eglash, R., Krishnamoorthy, M., Sanchez, J., \& Woodbridge, A. (2011). Fractal simulations of African design in pre-college computing education. ACM Transactions on Computing Education, 11(3), 1-14, doi:10.1145/2037276.2037281.

Fayer, S., Lacey, A., \& Watson, A. (2017). STEM occupations: Past, present, and future. Spotlight on statistics. Washington, DC: U.S. Department of Labor, Bureau of Labor Statistics. Retrieved from https://digitalcommons-ilr-cornelledu.mimas.calstatela.edu/cgi/viewcontent.cgi?referer=https://scholar.google.com /\&httpsredir=1\&article=2928\&context=key_workplace

Frederick, R., Donnor, J., \& Hatley, L. (2009). Culturally responsive applications of computer technologies in education: Examples of best practice. Educational Technology, 49(6), 9-13.

Frederick, R. (2007). Conductors of the digitized underground railroad: Black teachers empower pedagogies with computer technology. The Journal of Negro Education, 76(1), 68-79.

Gay, G. (2002). Preparing for culturally responsive teaching. Journal of Teacher Education, 53(2), 106-116. doi:10.1177/0022487102053002003

Gay, G. (2010). Culturally responsive teaching: Theory, research, and practice (2 ${ }^{\text {nd }}$ ed). Multicultural Education Series. New York, NY: Teachers College Press.

Gay, G. (2013) Teaching to and through cultural diversity. Curriculum Inquiry, 43(1), 4870. doi: 10.1111/curi.12002

Goode, J. (2008). Increasing diversity in k-12 computer science: Strategies from the field. Proceedings of the 39th SIGCSE Technical Symposium on Computer Science Education, 40(1), 362-366. doi:10.1145/1352135.1352259

Gorski, P., C. (2009). Insisting on digital equity: Reframing the dominant discourse on multicultural education and technology. Urban Education, 44(3), 348-364. doi:10.1177/0042085908318712

Green, B. N., Johnson, C. D., \& Adams, A. (2006). Writing narrative literature reviews for peer-reviewed journals: Secrets of the trade. Journal of Chiropractic Medicine, 5(3), 101-117. doi: 10.1016/S0899-3467(07)60142-6 
Grover, S., \& Pea, R. (2013). Computational thinking in k-12: A review of the state of the field. Educational Researcher, 42(1), 38-43.

Handly, M. A., Lyels, C. R., McCulloch, C., \& Cattamanchi, A. (2018). Selecting and improving quasi-experimental designs in effectiveness and implementation research. Annual Review of Public Health, 39(1), 5-25. Retrieved from https://doi.org/10.1146/annurev-publhealth-040617-014128

Howard, T. C., \& Clarence L. T. (2011). Culturally responsive pedagogy for African American students: Promising programs and practices for enhanced academic performance. Teaching Education, 22(4), 345-362. doi: $0.1080 /$ 10476210.2011.608424

Kafai, Y. B., Lee, E., Searle, K., Fields, D., Kaplan, E., \& Lui, D. (2014). A crafts-oriented approach to computing in high school: Introducing computational concepts, practices, and perspectives with electronic textiles. ACM Transactions on Computing Education, 14(1), 1-20. doi:10.1145/2576874

Kafai, Y. B., Fields, D. A., \& Searle, K. A. (2014). Electronic textiles as disruptive designs: Supporting and challenging maker activities in schools. Harvard Educational Review, 84(4), 532-556. doi:10.17763/haer.84.4.46m7372370214783

Kim, S., \& Slapac, A. (2015). Culturally responsive, transformative pedagogy in the transnational era: Critical perspectives. Educational Studies, 51(1), 17-27. doi:10.1080/00131946.2014.983639

Lachney, M. (2017) Culturally responsive computing as brokerage: Toward asset building with education-based social movements. Learning, Media and Technology, 42(4), 420-439. doi:10.1080/17439884.2016.1211679

Lachney, M., Babbitt, W., \& Eglash, R. (2016). Software design in the 'construction genre' of learning technology: Content aware versus content agonistic. Computational Culture: A Journal of Software Studies, 5, 1-15. Retrieved from http://computationalculture.net/article/software-design-in-the-construction-genreoflearning-technology-content-aware-versus-content-agnostic

Ladson-Billings, G. (1994). What we can learn from multicultural education research. Educational Leadership, 51(8), 22-26. Retrieved from https://eric.ed.gov/?id=EJ508261

Ladson-Billings, G. (1995a). But that's just good teaching! The case for culturally relevant pedagogy. Theory Into Practice, 34(3), 159-165.

Ladson-Billings, G. (1995b). Toward a theory of culturally relevant pedagogy. American Educational Research Journal, 32(3), 465-491.

Ladson-Billings, G. (2014). Culturally relevant pedagogy 2.0: Aka the remix. Harvard Educational Review, 84(1), 74-84. doi:10.17763/haer.84.1.p2rj131485484751

Lee, C. (2003). Toward a framework for culturally responsive design in multimedia computer environments: Cultural modeling as a case. Mind, Culture, and Activity, 10(1), 42-61. doi: 10.1207/S15327884MCA1001_05 
Lee, I., Martin, F., Denner, J., Coulter, B., Allan, W., Erickson, J., ... Werner, L. (2011). Computational thinking for youth in practice. ACM Inroads, 2(1), 32-37. doi: 10.1145/1929887.1929902

Lye, S. Y., \& Koh, J. H. L. (2014). Review on teaching and learning of computational thinking through programming: What is next for K-12? Computers in Human Behavior, 41, 51-61. doi:10.1016/j.chb.2014.09.012

Margolis, J. (2010). Stuck in the shallow end: Education, race, and computing. Boston, MA: MIT Press.

Margolis, J., Goode, J., \& Bernier, D. (2011). The need for computer science. Educational Leadership, 68(5), 68-72.

Papert, S. (1980). Mindstorms: Children, computers, and powerful ideas. New York, NY: Basic Books. Retrieved from http://worrydream.com/refs/Papert\%20$\% 20$ Mindstorms $\% 201$ st $\% 20$ ed.pdf

Peppler, K. (2013). STEAM-powered computing education: Using e-textiles to integrate the arts and STEM. Computer, 46(9), 38-43. doi:10.1109/MC.2013.257

Petticrew, M., \& Roberts, H. (2006). Systematic reviews in the social sciences: A practical guide. Malden, MA: Blackwell Publishing.

Pohawpatchoko, C., Colwell, C., Powell, J., \& Lassos, J. (2017). Developing a native digital voice: Technology and inclusivity in museums. Museum Anthropology, 40(1), 52-64. doi:10.1111/muan.12130

Popay, J., Roberts, H., Sowden, A., Petticrew, M., Arai, L., Rodgers, M., ... Duffy, S. (2006). Guidance on the conduct of narrative synthesis in systematic reviews. A Product from the ESRC Methods Programme, 1, 1-92. doi 10.13140/2.1.1018.4643

Prensky, M. (2001). Digital natives digital immigrants part 2: Do they really think differently? On The Horizon, 9(6), 3-16. doi: http://dx.doi.org/10.1108/10748120110424843

Prilleltensky, I. (2001). Value-based praxis in community psychology: Moving towards social justice and social action. American Journal of Community Psychology, 29(5), 747-778. doi: 10.1023/A:1010417201918

Scott, K., Aist, G., \& Hood, D. (2009). CompuGirls: Designing a culturally relevant technology program. Educational Technology, 49(6), 34-39.

Scott, K., Aist, G., Zhang, X. (2014) Designing a culturally responsive computing curriculum for girls. International Journal of Gender, Science, and Technology. 6(2). 264-276.

Scott, K. A., \& Garcia, P. (2016). Techno-social change agents: Fostering activist dispositions among girls of color. Meridians: feminism, race, transnationalism 15(1), 65-85. 
Scott, A., Martin, A., McAlear, F., \& Madkins, T. C. (2016). Broadening participation in computer science: Existing out-of-school initiatives and a case study. ACM Inroads, 7(4), 84-90. doi: 10.1145/2994153

Scott, K. A., Sheridan, K., \& Clark, K. (2015). Culturally responsive computing: A theory revisited. Learning, Media \& Technology, 40(4), 412-436. doi: 10.1080/17439884.2014.924966

Scott, K. A., \& White, M. A. (2013). COMPUGIRLS' standpoint: Culturally responsive computing and its effect on girls of color. Urban Education, 48(5), 657-681. doi: $10.1177 / 0042085913491219$

Tedre, M. (2002). Ethnocomputing: A multicultural view on computer science (Master's thesis). Retrieved from http://cs.joensuu.fi/ ethno/articles/ tedre_matti_ethnocomputing.pdf

Tedre, M., Sutinen, E., Kahkonen, E., \& Kommers, P. (2006). Ethnocomputing: ICT in cultural and social context. Communications of the ACM. 49(1), 126-130. doi: 10.1145/1107458.1107466

Tofel-Grehl, C., Fields, D., Searle, K., Maahs-Fladung, C., Feldon, D., Gu, G., \& Sun, C. (2017). Electrifying engagement in middle school science class: Improving student interest through e-textiles. Journal of Science Education and Technology, 26(4), 406-417. doi:10.1007/s10956-017-9688-y

Wang, J., Hong, H., Ravitz, J., \& Hejazi Moghadam, S. (2016). Landscape of K-12 computer science education in the US: Perceptions, access, and barriers. Proceedings of the 47th ACM Technical Symposium on Computing Science Education, ACM, 645-650. doi: 10.1145/2839509.2844628

Xie, Y., \& Reider, D. (2014). Integration of innovative technologies for enhancing students' motivation for science learning and career. Journal of Science Education and Technology, 23(3), 370-380. 
Appendix A: Complete List of Key Terms

\begin{tabular}{|l||}
\hline Ethnocomputing \\
Ethnocomputing + culture \\
Ethnocomputing + race \\
Ethnocomputing + minorities \\
\hline "Culturally responsive computing" \\
"Culturally responsive" + "computing" \\
"Culturally responsive" + "computing" + "race" \\
"Culturally responsive" + "computing" + "minorities" \\
\hline "E-textiles" \\
"E-textiles" + culture \\
"E-textiles" + race \\
"E-textiles" + minorities \\
\hline "Culturally situated design tools" \\
"Culturally situated design tools" + "race" \\
"Culturally situated design tools" + "minorities" \\
\hline "Ancestral computing" \\
"Ancestral computing" + culture \\
"Ancestral computing" + race \\
"Ancestral computing" + minorities \\
\hline "Computer programming" + culture \\
"Computer programming" + race \\
"Computer programming" + minorities \\
\hline Programming + culture \\
Computing + culture \\
"Computer science" + culture \\
"Computational thinking" + culture \\
\hline Note. Quotation marks were used as Boolean operations in order to \\
refine our searches \\
\hline
\end{tabular}




\section{Appendix B}

Table 1

Articles Retrieved from Keyword Culturally Responsive Computing

Table 2

Articles Retrieved from Keyword Culturally Situated Design Tools

Table 3

Articles Retrieved from Keyword E-textiles

Table 4

Articles Retrieved from Keyword Ethnocomputing 
Table 1

Articles Retrieved from Keyword Culturally Responsive Computing

\begin{tabular}{|c|c|c|c|c|c|}
\hline Author and Year & Purpose of Study & Participants & Method & Major Findings & Themes \\
\hline $\begin{array}{l}\text { Frederick, Donor, \& } \\
\text { Hatley (2009) }\end{array}$ & $\begin{array}{l}\text { To review existing literature } \\
\text { on the use of culturally } \\
\text { responsive computer } \\
\text { software technologies }\end{array}$ & $\mathrm{N} / \mathrm{A}$ & Literature review & $\begin{array}{l}\text { Culturally responsive } \\
\text { technologies in education } \\
\text { should involve lessons with } \\
\text { diverse representation, allow } \\
\text { for self-expression, build } \\
\text { cultural competency, and use } \\
\text { shared platforms }\end{array}$ & LE \\
\hline $\begin{array}{l}\text { Scott, Aist, \& Hood, } \\
(2009)\end{array}$ & $\begin{array}{l}\text { To present the design, } \\
\text { implementation, and lessons } \\
\text { learned from } \\
\text { COMPUGIRLS, a computing } \\
\text { program aimed to provide a } \\
\text { culturally relevant } \\
\text { multimedia program for girls } \\
\text { of color }\end{array}$ & $\begin{array}{l}\text { Girls of color ages } \\
13-18 \text { of } \\
\text { economically } \\
\text { challenged } \\
\text { backgrounds }\end{array}$ & $\begin{array}{l}\text { A case study outlining } \\
\text { aspects of a program }\end{array}$ & $\begin{array}{l}\text { When serving students of color, } \\
\text { a culturally relevant curriculum } \\
\text { involves lessons that are } \\
\text { student-centered, } \\
\text { customizable, and related to } \\
\text { real world problems }\end{array}$ & $\begin{array}{l}\text { SCR; } \\
\text { LE }\end{array}$ \\
\hline $\begin{array}{l}\text { Scott, \& White } \\
\text { (2013) }\end{array}$ & $\begin{array}{l}\text { To examine COMPUGIRLS, } \\
\text { a culturally responsive } \\
\text { computing program for girls } \\
\text { of color, with the notion of } \\
\text { evaluating the effectiveness } \\
\text { of CRC methods related to } \\
\text { asset building, } \\
\text { connectedness, and } \\
\text { reflection }\end{array}$ & $\begin{array}{l}\text { A total of } 41 \\
\text { African American, } \\
\text { Latina, White, and } \\
\text { Native American } \\
\text { low income girls } \\
\text { from urban } \\
\text { Southwest } \\
\text { schools, ages 13- } \\
18\end{array}$ & $\begin{array}{l}\text { A case study using } \\
\text { field notes from } \\
\text { observations and } \\
\text { interviews }\end{array}$ & $\begin{array}{l}\text { The thrill in the challenge of } \\
\text { COMPUGIRLS that allowed } \\
\text { participants to manipulate } \\
\text { media explained participants' } \\
\text { motivation to stay in the } \\
\text { program }\end{array}$ & SCR \\
\hline
\end{tabular}

Note. Authors organized articles chronologically, then alphabetically. HCA=heritage culture through artifacts; VA= vernacular culture; SCR= sociopolitical consciousness raising; $\mathrm{LE}=$ lived experiences; $\mathrm{CC}=$ community connections; $\mathrm{P}=$ personalization; $\mathrm{CRC}=$ culturally relevant computing; CSDT = Culturally Situated Design Tools 
Table 1 (continued)

Articles Retrieved from Keyword Culturally Responsive Computing (continued)

\begin{tabular}{|c|c|c|c|c|c|}
\hline Author and Year & Purpose of Study & Participants & Method & Major Findings & Themes \\
\hline $\begin{array}{l}\text { DiSalvo, Guzdial, } \\
\text { Bruckman, \& McKlin } \\
\text { (2014). }\end{array}$ & $\begin{array}{l}\text { To explore the use and } \\
\text { design implications of face- } \\
\text { saving tactics that Black } \\
\text { young men used to maintain } \\
\text { their current identities with } \\
\text { friends and families while } \\
\text { learning computer science } \\
\text { as game testers }\end{array}$ & $\begin{array}{l}\text { A total of } 30 \\
\text { African-American } \\
\text { and } 2 \text { Latino males } \\
\text { ages } 14-18 \text { years } \\
\text { old }\end{array}$ & $\begin{array}{l}\text { Observations, } \\
\text { interviews, surveys, } \\
\text { and focus groups were } \\
\text { collected to capture } \\
\text { participants' } \\
\text { experiences in } \\
\text { computer science } \\
\text { courses as game } \\
\text { testers }\end{array}$ & $\begin{array}{l}\text { Interest, confidence, and desire } \\
\text { for a career in computer science } \\
\text { increased; most participants } \\
\text { studied computer science after } \\
\text { high school; participants } \\
\text { developed ways to save face with } \\
\text { family and friends while retaining } \\
\text { an interest in the program }\end{array}$ & LE \\
\hline $\begin{array}{l}\text { Scott, Sheridan, \& } \\
\text { Clark (2015) }\end{array}$ & $\begin{array}{l}\text { To explain how CRC has } \\
\text { been applied in different } \\
\text { studies and propose ways to } \\
\text { improve current limitations } \\
\text { using five reconceptualized } \\
\text { tenets of CRC }\end{array}$ & Varied & $\begin{array}{l}\text { A theoretical article } \\
\text { reviewing prior } \\
\text { applications of CRC } \\
\text { followed by ways to } \\
\text { improve CRC } \\
\text { programming, } \\
\text { methods, and theory }\end{array}$ & $\begin{array}{l}\text { Five new tenets were created } \\
\text { centered on the notion of } \\
\text { considering students' } \\
\text { intersectional identities, } \\
\text { challenging deficit thinking, and } \\
\text { encouraging activism }\end{array}$ & $\begin{array}{l}\text { LE; } \\
\text { SCR }\end{array}$ \\
\hline Chuang (2016) & $\begin{array}{l}\text { To examine an online } \\
\text { learning group using cloud } \\
\text { computing and social media } \\
\text { to teach pre-service } \\
\text { teachers how to administer } \\
\text { lessons involving using } \\
\text { culturally relevant teaching } \\
\text { in technology education to } \\
\text { elementary children }\end{array}$ & $\begin{array}{l}\text { A total of } 31 \text { pre- } \\
\text { service teachers } \\
\text { from southern } \\
\text { Taiwan }\end{array}$ & $\begin{array}{l}\text { Individual and group } \\
\text { interviews were used } \\
\text { along with a brief } \\
\text { survey assessing } \\
\text { confidence in applying } \\
\text { culturally relevant } \\
\text { teaching on WebQuest }\end{array}$ & $\begin{array}{l}\text { Using online cloud computing and } \\
\text { social media helped facilitate the } \\
\text { online learning community to best } \\
\text { meet the needs of the teachers } \\
\text { and students }\end{array}$ & $\mathrm{CC}$ \\
\hline
\end{tabular}

Note. Authors organized articles chronologically, then alphabetically. $\mathrm{HCA}=$ heritage culture through artifacts; VA= vernacular culture; $\mathrm{SCR}=$ sociopolitical consciousness raising; $\mathrm{LE}=$ lived experiences; $\mathrm{CC}=$ community connections; $\mathrm{P}=$ personalization; $\mathrm{CRC}=$ culturally relevant computing; CSDT = Culturally Situated Design Tools

(continued) 
Table 1 (continued)

Articles Retrieved from Keyword Culturally Responsive Computing (continued)

\begin{tabular}{|c|c|c|c|c|c|}
\hline Author and Year & Purpose of Study & Participants & Method & Major Findings & Themes \\
\hline $\begin{array}{l}\text { Scott \& Garcia } \\
(2016)\end{array}$ & $\begin{array}{l}\text { To provide a critique of } \\
\text { neoliberal technology } \\
\text { approaches and in turn an } \\
\text { overview of lessons from a } \\
\text { CRC social justice-oriented } \\
\text { program for girls of color }\end{array}$ & $\begin{array}{l}\text { African American } \\
\text { and Latina girls } \\
\text { ages } 13-18 \text { of high } \\
\text { need }\end{array}$ & $\begin{array}{l}\text { A descriptive } \\
\text { qualitative case study } \\
\text { (program review) } \\
\text { detailing the creation } \\
\text { and implementation of } \\
\text { a program followed by } \\
\text { sample lessons }\end{array}$ & $\begin{array}{l}\text { The program and lessons aimed } \\
\text { to create critical users and } \\
\text { producers of technology that can } \\
\text { challenge the status quo and } \\
\text { become agents of change }\end{array}$ & $\begin{array}{l}\text { SCR; } \\
\text { LE }\end{array}$ \\
\hline $\begin{array}{l}\text { Ashcraft Eger \& } \\
\text { Scott (2017) }\end{array}$ & $\begin{array}{l}\text { To describe and evaluate } \\
\text { two practices of CRC in } \\
\text { relation to identity } \\
\text { development and social } \\
\text { justice for girls of color } \\
\text { within cohorts }\end{array}$ & $\begin{array}{l}\text { A total of } 14 \text { Black, } \\
\text { Latina, and mixed } \\
\text { race girls in } 8 \text { th to } \\
9 \text { th grade from a } \\
\text { lower income } \\
\text { region of Denver }\end{array}$ & $\begin{array}{l}\text { A two-year } \\
\text { ethnography involving } \\
\text { a three-week summer } \\
\text { with three courses on } \\
\text { computation. Student } \\
\text { artifacts and interviews } \\
\text { were also collected }\end{array}$ & $\begin{array}{l}\text { Discourse on topics of } \\
\text { intersecting ideas began as a } \\
\text { difficult topic for participants and } \\
\text { evolved to insightful perspectives } \\
\text { on inequality. Participants } \\
\text { eventually developed identities as } \\
\text { technosocial change agents }\end{array}$ & $\begin{array}{l}\text { SCR } \\
\text { LE }\end{array}$ \\
\hline Lachney (2017) & $\begin{array}{l}\text { To explore two approaches } \\
\text { to using CSDT as a } \\
\text { mechanism to promote } \\
\text { connections and social } \\
\text { justice movements within } \\
\text { schools and communities }\end{array}$ & $\begin{array}{l}\text { Case } 1 \text { involved } \\
\text { teachers, software } \\
\text { developers, and } \\
\text { hair braiders; Case } \\
2 \text { described } \\
\text { implementing a } \\
\text { curriculum for } \\
\text { math and art } \\
\text { teachers from New } \\
\text { York City }\end{array}$ & $\begin{array}{l}\text { A descriptive } \\
\text { qualitative review of } \\
\text { two case studies } \\
\text { involving CRC } \\
\text { approaches explaining } \\
\text { the design and } \\
\text { implementation of } \\
\text { projects and the } \\
\text { lessons learned }\end{array}$ & $\begin{array}{l}\text { CRC can be used to create } \\
\text { mutually beneficial brokering } \\
\text { strategies that bridge a wealth of } \\
\text { community knowledge to } \\
\text { education and to creating asset } \\
\text { building }\end{array}$ & $\mathrm{CC}$ \\
\hline
\end{tabular}

Note. Authors organized articles chronologically, then alphabetically. HCA=heritage culture through artifacts; VA= vernacular culture; SCR= sociopolitical consciousness raising; $\mathrm{LE}=$ lived experiences; $\mathrm{CC}=$ community connections; $\mathrm{P}=$ personalization; $\mathrm{CRC}=$ culturally relevant computing; CSDT = Culturally Situated Design Tools 
Table 2

Articles Retrieved from Keyword Culturally Situated Design Tools

\begin{tabular}{|c|c|c|c|c|c|}
\hline Author and Year & Purpose & Participants & Method & Major Findings & Themes \\
\hline $\begin{array}{l}\text { Eglash, Bennett, } \\
\text { O'Donnell, } \\
\text { Jennings, \& } \\
\text { Cintorino (2006) }\end{array}$ & $\begin{array}{l}\text { To review programs } \\
\text { conducted on the } \\
\text { implementation of CSDT } \\
\text { with preliminary research } \\
\text { on the advantages and } \\
\text { dangers of this work }\end{array}$ & $\begin{array}{l}\text { African American, } \\
\text { Latino, Native } \\
\text { American and } \\
\text { White samples }\end{array}$ & $\begin{array}{l}\text { A descriptive review of } \\
\text { CSDT tools and } \\
\text { various programs } \\
\text { using this technique } \\
\text { followed by evaluation } \\
\text { studies and } \\
\text { recommendations }\end{array}$ & $\begin{array}{l}\text { Preliminary data on CSDT } \\
\text { applications showed increases } \\
\text { in math achievement }\end{array}$ & $\begin{array}{l}\text { VA } \\
\text { HCA }\end{array}$ \\
\hline $\begin{array}{l}\text { Eglash \& Bennett } \\
\text { (2009) }\end{array}$ & $\begin{array}{l}\text { To explore a CSDT } \\
\text { software program called } \\
\text { Cornrow Curves aimed to } \\
\text { bridge African American } \\
\text { cultural hair traditions to } \\
\text { computational geometry, } \\
\text { and identity development }\end{array}$ & $\begin{array}{l}\text { African American } \\
\text { and Latino middle } \\
\text { school students } \\
\text { from low income } \\
\text { backgrounds }\end{array}$ & $\begin{array}{l}\text { A descriptive } \\
\text { quantitative review of } \\
\text { a case study using } \\
\text { CSDT followed by its } \\
\text { evaluation using } \\
\text { surveys and a quasi- } \\
\text { experiment assessing } \\
\text { math performance }\end{array}$ & $\begin{array}{l}\text { Positive anecdotal feedback } \\
\text { from users and evaluation } \\
\text { results showed an increase in } \\
\text { positive attitudes toward } \\
\text { careers in technology and } \\
\text { math performance }\end{array}$ & VA \\
\hline $\begin{array}{l}\text { Eglash, } \\
\text { Krishnamoorthy, } \\
\text { Sanchez \& } \\
\text { Woodbridge (2011) }\end{array}$ & $\begin{array}{l}\text { To test the effectiveness of } \\
\text { an intervention of a web } \\
\text { based program that uses } \\
\text { Java simulations of African } \\
\text { designs to teach } \\
\text { computational perspectives } \\
\text { on fractals to high school } \\
\text { students }\end{array}$ & $\begin{array}{l}\text { Two 10th grade } \\
\text { computing } \\
\text { classes with a } \\
\text { total of } 40 \\
\text { students }\end{array}$ & $\begin{array}{l}\text { A quasi-experimental } \\
\text { design with } \\
\text { assignment to an } \\
\text { intervention or no } \\
\text { intervention class }\end{array}$ & $\begin{array}{l}\text { Both performance and } \\
\text { attitudes towards STEM were } \\
\text { enhanced for the intervention } \\
\text { sample using the cultural } \\
\text { design approach }\end{array}$ & $\mathrm{HCA}$ \\
\hline
\end{tabular}

Note. Authors organized articles chronologically, then alphabetically. HCA=heritage culture through artifacts; VA= vernacular culture; SCR= sociopolitical consciousness raising; $\mathrm{LE}=$ lived experiences; $\mathrm{CC}=$ community connections; $\mathrm{P}=$ personalization; $\mathrm{CRC}=$ culturally relevant computing; CSDT = Culturally Situated Design Tools 
Table 2 (continued)

Articles Retrieved from Keyword Culturally Situated Design Tools (continued)

\begin{tabular}{|c|c|c|c|c|c|}
\hline Author and Year & Purpose & Participants & Method & Major Findings & Themes \\
\hline $\begin{array}{l}\text { Eglash, Gilbert, } \\
\text { Taylor, \& Geier } \\
\text { (2013) }\end{array}$ & $\begin{array}{l}\text { A comparison and } \\
\text { evaluation of two } \\
\text { pilot designs using } \\
\text { CRC: One targeting } \\
\text { vernacular culture } \\
\text { and the other } \\
\text { heritage culture }\end{array}$ & $\begin{array}{l}\text { Youth (grades 1-6) from } \\
\text { Texas, Alabama, and New } \\
\text { York; } 81 \text { were assessed } \\
\text { across four waves of time, } \\
\text { each varying in gender, } \\
\text { grade, and ethnicity }\end{array}$ & $\begin{array}{l}\text { A descriptive } \\
\text { quantitative review } \\
\text { and quasi- } \\
\text { experiment } \\
\text { evaluating two } \\
\text { pilot programs. } \\
\text { Math attitudes } \\
\text { were evaluated } \\
\text { using a skills test, } \\
\text { interviews, } \\
\text { surveys, and other } \\
\text { tools }\end{array}$ & $\begin{array}{l}\text { Improvement in interests and } \\
\text { attitudes were found; } \\
\text { participants also ranked } \\
\text { vernacular over heritage } \\
\text { approaches }\end{array}$ & $\begin{array}{l}\text { HCA; } \\
\text { VA }\end{array}$ \\
\hline $\begin{array}{l}\text { Babbitt, Lachney, } \\
\text { Bulley, \& Eglash } \\
\text { (2015) }\end{array}$ & $\begin{array}{l}\text { To describe the } \\
\text { design, } \\
\text { implementation, and } \\
\text { evaluation of a case } \\
\text { study using } \\
\text { ethnocomputing by } \\
\text { applying Ghanian } \\
\text { Adinkra-related } \\
\text { symbols of } \\
\text { computing when } \\
\text { teaching a math } \\
\text { lesson }\end{array}$ & $\begin{array}{l}\text { Software developers created } \\
\text { the computing software and } \\
20 \text { middle school students } \\
\text { from Ghana partook in the } \\
\text { evaluation of the program } \\
\text { implementation }\end{array}$ & $\begin{array}{l}\text { A descriptive } \\
\text { quantitative case } \\
\text { study and quasi- } \\
\text { experimental } \\
\text { evaluation of } \\
\text { CSDT tools for } \\
\text { math education }\end{array}$ & $\begin{array}{l}\text { Participants exposed to the } \\
\text { culturally relevant software, } \\
\text { compared to the control group, } \\
\text { exhibited improvements in } \\
\text { knowledge learned from the } \\
\text { lesson }\end{array}$ & $\mathrm{HCA}$ \\
\hline
\end{tabular}

Note. Authors organized articles chronologically, then alphabetically. $\mathrm{CR}=$ culturally relevant; $\mathrm{CRC}=$ culturally responsive computing; $\mathrm{HCA}=$ heritage culture through artifacts; $\mathrm{VA}=$ vernacular culture; $\mathrm{SCR}=$ sociopolitical consciousness raising; $\mathrm{LE}=$ lived experiences; $\mathrm{CC}=$ community connections; $\mathrm{P}=$ personalization; CSDT = Culturally Situated Design Tools 
Table 3

Articles Retrieved from Keyword E-textiles

\begin{tabular}{|c|c|c|c|c|c|}
\hline Author and Year & Purpose of Study & Participants & Method & Major Findings & Themes \\
\hline $\begin{array}{l}\text { Kafai, Fields, \& } \\
\text { Searle (2014) }\end{array}$ & $\begin{array}{l}\text { To examine the } \\
\text { experiences of high school } \\
\text { participants who learned to } \\
\text { use e-textiles through } \\
\text { workshops }\end{array}$ & $\begin{array}{l}\text { A total of } 35 \text { male } \\
\text { and female } \\
\text { students from the } \\
\text { Mid Atlantic, ages } \\
\text { 14-15 of African } \\
\text { American, } \\
\text { Caucasian, Asian, } \\
\text { and mixed } \\
\text { ethnicity }\end{array}$ & $\begin{array}{l}\text { Video recordings, } \\
\text { photographs of } \\
\text { activities, daily field } \\
\text { notes, and interviews } \\
\text { regarding e-textile } \\
\text { workshops were used }\end{array}$ & $\begin{array}{l}\text { E-textiles allowed students to } \\
\text { engage in a technology that } \\
\text { focused on transparency, } \\
\text { aesthetics, and diversity, } \\
\text { specifically gender diversity in } \\
\text { the learning process }\end{array}$ & $P$ \\
\hline $\begin{array}{l}\text { Kafai, Lee, Searle, } \\
\text { Fields, Kaplan \& Lui } \\
(2014)\end{array}$ & $\begin{array}{l}\text { To outline the feasibility of } \\
\text { implementing a high school } \\
10 \text {-week curriculum on e- } \\
\text { textiles using the LilyPad } \\
\text { Arduino software and } \\
\text { evaluate its impact on } \\
\text { students' perceptions of } \\
\text { computing }\end{array}$ & $\begin{array}{l}\text { A ethnically and } \\
\text { socioeconomic } \\
\text { diverse group of } \\
1516-18 \text {-year-old } \\
\text { students from a } \\
\text { pre-AP computer } \\
\text { science course }\end{array}$ & $\begin{array}{l}\text { Student portfolios and } \\
\text { pre/post project } \\
\text { interviews with } \\
\text { students were used } \\
\text { as a means to reflect } \\
\text { on their designs }\end{array}$ & $\begin{array}{l}\text { Reflections showed an } \\
\text { increase in computing } \\
\text { relevance, in their identities as } \\
\text { programmers, and in an } \\
\text { understanding of } \\
\text { programming and computer } \\
\text { science as a field }\end{array}$ & $P$ \\
\hline $\begin{array}{l}\text { Tofel-Grehl, Fields, } \\
\text { Searle, Maahs- } \\
\text { Fladung, Feldon, } \\
\text { Gu, \& Sun (2017) }\end{array}$ & $\begin{array}{l}\text { To examine the } \\
\text { implementation of an e- } \\
\text { textiles middle school } \\
\text { science curriculum and its } \\
\text { impact on student learning } \\
\text { outcomes }\end{array}$ & $\begin{array}{l}\text { A total of } 155 \text { 8th } \\
\text { grade students in } \\
\text { eight science } \\
\text { classes }\end{array}$ & $\begin{array}{l}\text { Field notes, surveys, } \\
\text { and a quasi- } \\
\text { experimental design } \\
\text { with the treatment } \\
\text { being the e-textile } \\
\text { curriculum and the } \\
\text { control group a } \\
\text { traditional hands-on } \\
\text { activity }\end{array}$ & $\begin{array}{l}\text { The e-textiles treatment group } \\
\text { showed more positive } \\
\text { perceptions of science, } \\
\text { greater perceived parental } \\
\text { value of projects, and reported } \\
\text { support for interpersonal } \\
\text { connections }\end{array}$ & $P$ \\
\hline
\end{tabular}

Note. Authors organized articles chronologically, then alphabetically. $\mathrm{CR}=$ culturally relevant; $\mathrm{CRC}=$ culturally responsive computing; $\mathrm{HCA}=$ heritage culture through artifacts; $\mathrm{VA}=$ vernacular culture; $\mathrm{SCR}=$ sociopolitical consciousness raising; $\mathrm{LE}=$ lived experiences; $\mathrm{CC}=$ community connections; $\mathrm{P}=$ personalization; CSDT = Culturally Situated Design Tools 
Table 4

Articles Retrieved from Keyword Ethnocomputing

\begin{tabular}{|c|c|c|c|c|c|}
\hline Author and Year & Purpose of Study & Participants & Method & Major Findings & Themes \\
\hline $\begin{array}{l}\text { Tedre, Sutinen, } \\
\text { Kähkönen, \& } \\
\text { Kommers (2006) }\end{array}$ & $\begin{array}{l}\text { To examine the } \\
\text { shortcomings of ICT } \\
\text { approaches and introduce } \\
\text { ethnocomputing as a } \\
\text { theoretical framework } \\
\text { aimed to facilitate the use } \\
\text { and application of ICT by } \\
\text { making it relevant to the } \\
\text { user's own culture }\end{array}$ & N/A & $\begin{array}{l}\text { A theoretical } \\
\text { discussion }\end{array}$ & $\begin{array}{l}\text { ICT is bounded by the current } \\
\text { technological capacities, the } \\
\text { needs of users, the relevance } \\
\text { to users, and the relevance to } \\
\text { cultural groups; in turn, using } \\
\text { ethnocomputing could benefit } \\
\text { and complement cultures not } \\
\text { undermine them }\end{array}$ & LE \\
\hline $\begin{array}{l}\text { Xie \& Reider } \\
(2014) .\end{array}$ & $\begin{array}{l}\text { To provide an overview of } \\
\text { the design, implementation, } \\
\text { and evaluation of a } \\
\text { program using GIS and IA } \\
\text { technologies with students } \\
\text { using references to popular } \\
\text { culture and real-world } \\
\text { scenarios }\end{array}$ & $\begin{array}{l}\text { A total of } 814 \\
\text { urban youth from } \\
\text { underserved } \\
\text { regions of the City } \\
\text { of Detroit }\end{array}$ & $\begin{array}{l}\text { An intervention project } \\
\text { was described } \\
\text { followed by surveys } \\
\text { and interviews for the } \\
\text { evaluation of learning } \\
\text { outcomes }\end{array}$ & $\begin{array}{l}\text { An increase in GIS and } \mathrm{Al} \\
\text { interest and knowledge was } \\
\text { found }\end{array}$ & LE \\
\hline $\begin{array}{l}\text { Anohah \& Suhonen, } \\
(2016) \text {. }\end{array}$ & $\begin{array}{l}\text { To review current research } \\
\text { on ethnocomputing with the } \\
\text { focus on cultural heritage in } \\
\text { order to develop a } \\
\text { framework for computing } \\
\text { educators to apply this } \\
\text { work to non-Western } \\
\text { contexts }\end{array}$ & $\mathrm{N} / \mathrm{a}$ & $\begin{array}{l}\text { A literature review and } \\
\text { framework } \\
\text { construction }\end{array}$ & $\begin{array}{l}\text { Prior applications of } \\
\text { ethnocomputing involve the } \\
\text { implementation and evaluation } \\
\text { of cultural awareness and } \\
\text { adoptability }\end{array}$ & $\mathrm{HCA}$ \\
\hline
\end{tabular}

Note. Authors organized articles chronologically, then alphabetically. $\mathrm{CR}=$ culturally relevant; $\mathrm{CRC}=$ culturally responsive computing;

$\mathrm{HCA}=$ heritage culture through artifacts; $\mathrm{VA}=$ vernacular culture; $\mathrm{SCR}=$ sociopolitical consciousness raising; $\mathrm{LE}=$ lived experiences; $\mathrm{CC}=$

community connections; $\mathrm{P}=$ personalization; $C S D T=$ Culturally Situated Design Tools; $I C T=$ information and communication technologies 
Table 4 (continued)

Articles Retrieved from Keyword Ethnocomputing (continued)

\begin{tabular}{|c|c|c|c|c|c|}
\hline Author and Year & Purpose of Study & Participants & Method & Major Findings & Themes \\
\hline $\begin{array}{l}\text { Eglash Bennett, } \\
\text { Drazan, Lachney, \& } \\
\text { Babbitt (2017) }\end{array}$ & $\begin{array}{l}\text { To review generative } \\
\text { justice approaches in the } \\
\text { ethnosciences that attempt } \\
\text { to use a respectful, } \\
\text { thoughtful, and } \\
\text { participatory design } \\
\text { process }\end{array}$ & $\mathrm{N} / \mathrm{A}$ & $\begin{array}{l}\text { A qualitative review of } \\
\text { three ethnoscience } \\
\text { approaches, including } \\
\text { ethnocomputing, } \\
\text { followed by initial pre- } \\
\text { post results from } \\
\text { these approaches }\end{array}$ & $\begin{array}{l}\text { A generative justice approach } \\
\text { should not assume that the } \\
\text { cultural knowledge is already } \\
\text { present in the participants; } \\
\text { instead, researchers should } \\
\text { be active social theorists and } \\
\text { use a respectful participatory } \\
\text { process, which increases } \\
\text { math and computing skills }\end{array}$ & $\begin{array}{l}\text { SCR; } \\
\text { VA }\end{array}$ \\
\hline $\begin{array}{l}\text { Pohawpatchoko, } \\
\text { Colwell, Powell, \& } \\
\text { Lassos (2017) }\end{array}$ & $\begin{array}{l}\text { To review an NSF funded } \\
\text { two-week program that } \\
\text { brought Native American } \\
\text { high school students into a } \\
\text { museum in order to } \\
\text { practice web-based } \\
\text { computer science that is } \\
\text { culturally relevant }\end{array}$ & $\begin{array}{l}\text { A total of } 10 \text { high } \\
\text { school Native } \\
\text { American interns }\end{array}$ & $\begin{array}{l}\text { A descriptive } \\
\text { qualitative case study } \\
\text { reviewing the } \\
\text { implementation of a } \\
\text { Pilot Program/ } \\
\text { Workshop }\end{array}$ & $\begin{array}{l}\text { While the workshop did not } \\
\text { change museum approaches } \\
\text { to culture, it provided interns } \\
\text { with exposure to technical } \\
\text { web skills, connectedness to } \\
\text { the museum, and a starting } \\
\text { point for inclusivity to museum } \\
\text { display approaches }\end{array}$ & $\mathrm{CC}$ \\
\hline
\end{tabular}

Note. Authors organized articles chronologically, then alphabetically. $\mathrm{CR}=$ culturally relevant; $\mathrm{CRC}=$ culturally responsive computing; $\mathrm{HCA}=$ heritage culture through artifacts; $\mathrm{VA}=$ vernacular culture; $\mathrm{SCR}=$ sociopolitical consciousness raising; $\mathrm{LE}=$ lived experiences; $\mathrm{CC}=$ community connections; $\mathrm{P}=$ personalization; $C R C=$ culturally relevant computing; ICT = information and communication technologies 


\section{Author Contact}

Jessica Morales-Chicas: jmora163@calstatela.edu

Cal State University, Los Angeles, 5151 State University Dr, Los Angeles, CA 90032, U.S.A.

Mauricio Castillo: mcastil2@exchange.calstatela.edu

Cal State University, Los Angeles, 5151 State University Dr, Los Angeles, CA 90032, U.S.A.

Ireri Bernal: ibernal7@calstatela.edu

Cal State University, Los Angeles, 5151 State University Dr, Los Angeles, CA 90032, U.S.A.

Paloma Ramos: pramos11@calstatela.edu

Cal State University, Los Angeles, 5151 State University Dr, Los Angeles, CA 90032, U.S.A.

Bianca L. Guzman: bguzman@exchange.calstatela.edu

Cal State University, Los Angeles, 5151 State University Dr, Los Angeles, CA 90032, U.S.A. 